\title{
ZASTUPLJENOST VISOKOOBRAZOVANIH POLAZNIKA U PROGRAMIMA TRAJNE IZOBRAZBE CENTRA ZA STALNO STRUČNO USAVRŠAVANJE KNJIŽNIČARA U RH
}

\author{
THE REPRESENTATION OF HIGHLY EDUCATED \\ ATTENDEES IN THE LIFELONG LEARNING PROGRAMS \\ AT THE CENTER FOR CONTINUING EDUCATION \\ OF LIBRARIANS IN CROATIA
}

\author{
Antonija Filipeti \\ Nacionalna i sveučilišna knjižnica u Zagrebu \\ afilipeti@nsk.hr
}

UDK / UDC 023: 374.7(497.5)

Stručni rad / Professional paper

Primljeno / Received: 21. 9. 2018.

Prihvaćeno / Accepted: 5. 2. 2019.

\section{Sažetak}

Cilj. Budući da su tečajevi Centra za stalno stručno usavršavanje knjižničara u RH (CSSU), prije svega, namijenjeni cjeloživotnom učenju te stalnom stručnom usavršavanju polaznika nakon formalnog, odnosno visokoškolskog obrazovanja, cilj rada bio je prikazati strukturu polaznika prema stručnoj spremi te utvrditi udio visokoobrazovanih polaznika u programima izobrazbe te godine radnog staža u struci unutar te skupine. Namjera je također bila pružiti pregled najzastupljenijih tema stručnog usavršavanja, odnosno tema od interesa za diplomirane knjižničare, kao i pregled podataka o zadovoljstvu predavačima, sadržajima tečajeva, primjenjivosti tečajeva na radno mjesto te spremnosti polaznika da sadržaj tečajeva na kojima su sudjelovali preporuče svojim kolegama.

Pristup. Na temelju pregleda statističkih podataka prikupljanih evaluacijskim upitnicima nakon odslušanih tečajeva CSSU-a te arhivskih dokumenata od 2013. do 2017. godine, analizira se zastupljenost diplomiranih knjižničara u programima trajne izobrazbe, radni staž u struci te interes vezan uz određena područja stručnog usavršavanja. Ta-

Vjesnik bibliotekara Hrvatske 62, 1(2019), 237-254

ISSN 0507-1925

(C) VBH 2018. 
kođer se promatra njihovo zadovoljstvo obrazovnim sadržajem i predavačima te razina mogućnosti primjene na postojećem radnome mjestu. Dobiveni rezultati prikazani su s osvrtom na trendove kretanja.

Ograničenja. U obzir su uzeti raspoloživi arhivski podaci. Također je naznačeno odstupanje popunjenih evaluacijskih listića od ukupnog broja polaznika.

Pitanje vezano uz stručnu spremu polaznika, koje se nalazi u evaluacijskim upitnicima, može uključivati i polaznike iz drugih ustanova, kao što su arhivi, muzeji i škole, no njihov broj, prema arhivskoj dokumentaciji, u promatranom razdoblju iznosi u prosjeku oko $2 \%$ godišnje.

Rezultati. Na temelju prikazanih podataka može se zaključiti kako u stalnom stručnom usavršavanju u okviru CSSU-a sudjeluje najviše visokoobrazovanih polaznika, odnosno diplomiranih knjižničara koji imaju do 10 godina radnog staža, no treba spomenuti da su zastupljeni i polaznici sa srednjom i višom stručnom spremom te polaznici s magisterijem znanosti, odnosno doktoratom, kojih ima najmanje. Pri analizi interesa za pojedine segmente knjižničnog poslovanja treba uzeti u obzir da su određena područja više zastupljena godišnjim programima. Važno je istaknuti visoku razinu zadovoljstva ponuđenim sadržajima te predavačima CSSU-a, kao i spremnost velike većine polaznika da preporuče tečaj na kojem su sudjelovali kolegama iz struke, što govori u prilog svrhovitosti ponuđenih obrazovnih sadržaja.

Originalnost/vrijednost. Iz priloženih rezultata vidljivo je kako knjižničari s različitim radnim iskustvom, odnosno godinama staža sudjeluju u programima stalne izobrazbe iako se njihov udio smanjuje s radnim vijekom. Prikazani podaci vezani uz zastupljenost diplomiranih knjižničara, odnosno polaznika s visokoškolskim obrazovanjem, u programu CSSU-a upućuju na važnost trajne izobrazbe nakon završenog formalnog obrazovanja, kao i nužnost usavršavanja u različitim područjima vezanim uz struku. S obzirom na trend kretanja broja polaznika koji sudjeluju u programima stručnog usavršavanja te razinu njihova zadovoljstva ponuđenim sadržajima, moguće je pratiti potrebe i interese polaznika te u skladu s tim prilagođavati teme edukacije $i$ povećavati njezinu dostupnost.

Ključne riječi: Centar za stalno stručno usavršavanje knjižničara u RH, neformalno obrazovanje, stručna sprema polaznika, teme stručnog usavršavanja.

\section{Abstract}

Purpose. Since the courses of the Center for Continuing Education of Librarians in Croatia (CSSU) are primarily aimed at lifelong learning and continuing professional training of librarians after they complete formal or higher education, the purpose of the work was to show the structure of the attendees according to the professional qualification and to determine the proportion of highly educated participants in the learning programs as well as the length of work experience in the profession. The purpose was also to provide an overview of the most represented topics of professional development, i.e. the interests 
of graduate librarians, as well as the data on lecturers' satisfaction, the content of the courses, the applicability of the courses at the workplace, and the attendees' willingness to recommend the content of the training they participated in to their colleagues.

Approach. Based on the review of the statistical data collected by the evaluation questionnaires filled in by the participants after the CSSU courses and the archive documents from 2013 to 2017, the attendance of graduate librarians in continuing education programs, work experience in the profession, and interest in certain areas of vocational training are analyzed. Their satisfaction with educational content and lecturers, as well as the level of applicability at their current workplaces, are also examined. The results obtained are presented with reference to current trends.

Research limitations. The research is based on the available archive information. The differences in the total number of the filled out evaluation questionnaires and the total number of participants in the observed period are also indicated.

The question regarding the attendees' professional qualification, which is in the evaluation questionnaires, shows that the attendees may come from other institutions such as archives, museums and schools, but their number, according to the archive documentation, is less than $2 \%$ per annum in the observed period.

Findings. The results have shown that the librarians who have up to 10 years of work experience and university graduates make the biggest share of participants in the programs of the Center for Continuing Education of Librarians, but there is also a certain percentage of the attendees with a two-year degree, with an MA or a $\mathrm{PhD}$ degrees. The percentage of the participants with the doctorate degree is the lowest.

When analyzing the interest for particular segments of library professional activities, it should be taken into account that certain areas are more represented in the annual programs. It is important to emphasize the high level of satisfaction with the offered contents and the CSSU lecturers, as well as the willingness of the vast majority of participants to recommend the training they attended to their colleagues, which speaks in favor of the purposefulness of the offered educational content.

Originality/Value. It is evident from the given results that librarians with different work experience, or years of service, participate in the programs of continuing education, although their share decreases with the length of the work career. The data presented in relation to the representation of graduated librarians or partecipants with higher education in the CSSU program indicate the importance of continuing education after completing formal education, as well as the necessity of training in various areas related to the profession. Given the number of attendees participating in vocational training programs and the level of their satisfaction with the offered content, it is possible to monitor the needs and interests of the attendees, and accordingly adapt the topics of education and increase their accessibility.

Keywords: Center for Continuing Education of Librarians in Croatia, non-formal education, professional qualification of participants, relevant topics of professional training 


\section{Uvod}

U svjetlu društveno-ekonomskih promjena na globalnoj razini, kao i stalnog razvoja tehnologije, mijenja se uloga knjižnica, a samim time i uloga knjižničara. Knjižnice postaju mjesta dinamičnog posredovanja, ali i cirkulacije informacija putem niza novih službi i usluga u vidu institucijskih repozitorija, virtualnih izložbi, primjene novih tehnologija u radu s djecom i mladima, inkluzije osjetljivijih društvenih skupina itd. Osim toga, knjižničari sve više napuštaju tradicionalne okvire struke sudjelujući u programima učenja i razmjene iskustava na daljinu, surađujući s nastavnicima u poticanju informacijske i informatičke pismenosti, ali i primjenjujući nove usluge te oblike komunikacije s korisnicima. U tom kontekstu treba spomenuti koncept uklopljenog knjižničarstva ${ }^{1}$, koji podrazumijeva inovativan pristup korisničkim zahtjevima i potrebama u smislu povezanosti i bliske suradnje s određenom zajednicom korisnika. Njegova je prednost anticipiranje informacijskih potreba, osiguravanje protoka informacija u okviru cijele zajednice, razvijen poslovni odnos između knjižničara i članova skupine korisnika, pri čemu knjižničar postaje integralnim dijelom korisničke skupine. ${ }^{2}$

U skladu s tim, valja naglasiti da se mijenja i koncept učenja postajući sve više procesom koji traje čitavog života i ne prestaje formalnim obrazovanjem, a znanja i vještine neprestano se trebaju obnavljati kako bi se išlo ukorak $s$ vremenom. Formalno obrazovanje stječe se školovanjem te je riječ o najviše organiziranom obliku učenja, strukturiranom u okviru obrazovne institucije, koje podrazumijeva certifikat, odnosno diplomu kojom se priznaje određeni stupanj obrazovanja. ${ }^{3}$

Međutim u današnje vrijeme sama svjedodžba postaje tek preduvjet za ulazak na tržište rada, a naglasak se stavlja na druge oblike učenja - kao što su neformalno i informalno učenje - u svrhu osposobljavanja polaznika za prilagodbu.

Neformalno obrazovanje podrazumijeva organizirane aktivnosti učenja s ciljem unapređenja znanja, vještina i kompetencija za osobne, društvene i profesionalne potrebe. Osnovna vrijednost takva oblika edukacije brzo je prilagođavanje potrebama tržišta rada. Informalno učenje odvija se bez izvanjske organizirane pomoći, no ipak podrazumijeva namjeru i plan osobe koja uči. ${ }^{4}$

Centar za stalno stručno usavršavanje knjižničara u RH (CSSU) kontinuirano provodi programe stalnog stručnog usavršavanja knjižničara i informacijskih stručnjaka od 2002. godine.

\footnotetext{
1 Machala, D. Uklopljeno knjižničarstvo: model knjižničarske djelatnosti novog vremena. // Revija Knjižnica 60, 1(2016), str. 119. [citirano: 2018-09-20]. Dostupno na: https://knjiznica. zbds-zveza.si/knjiznica/issue/view/575.

2 Shumaker, D. Embedded librarian: innovative strategies for taking knowledge where it's needed. Medford, New Jersey: Information today, 2012. Citirano prema: Machala, D. Nav. dj. str. 120.

3 Pastuović. N. Cjeloživotno učenje i promjene u školovanju. // Odgojne znanosti 10, 2(2008), str. 255-256. [citirano: 2018-07-20]. Dostupno na: https://hrcak.srce.hr/index.php?show=clanak\&id clanak jezik=46484

4 Machala, D. Knjižničarske kompetencije: pogled na razvoj profesije. Zagreb: Hrvatska sveučilišna naklada: Nacionalna i sveučilišna knjižnica, 2015. Str. 198-199.
} 
Osnovna namjena CSSU-a ogleda se u provedbi cjeloživotnog učenja nakon formalnog, odnosno inicijalnog visokoškolskog obrazovanja, a temelji se na propisanom godišnjem programu usavršavanja. U planu i programu naznačeni su ciljevi, sadržaji, preduvjeti za pristupanje pojedinim radionicama, metode poučavanja te literatura. Program se izvodi u obliku jednodnevnih tečajeva, koji traju do 5 sati. Program nije obvezan, a nakon završetka tečaja polaznici dobivaju potvrde o sudjelovanju. ${ }^{5}$

Dobivene potvrde polaznici mogu priložiti u svrhu napredovanja u više stručno zvanje ili primjerice pri traženju novoga radnog mjesta u svrhu prikaza aktivnosti usavršavanja u struci te vlastitih profesionalnih interesa.

Program CSSU-a ažurira se svake godine. Na mrežnim stranicama CSSU-a trajno je otvoren i dostupan poziv na predlaganje novih tečajeva. Tečajevi se prikupljaju tijekom cijele godine te se pri kraju tekuće godine, u suradnji s Programskim odborom (stručnim tijelom koje koordinira radom CSSU-a), donosi program za iduću godinu. Pritom se u program uključuju novi sadržaji, odnosno tematske cjeline, u skladu s aktualnim promjenama u struci, te se ažuriraju, odnosno, prema potrebi, isključuju iz programa postojeći tečajevi.

Program Centra modularno je strukturiran, a osim osnovnih tečajeva, u prikazanom razdoblju od 2013. do 2017. godine sadrži tečajeve za predavače CSSU-a Prezentacijske vještine i Komunikacijske vještine, nudi pregled tečajeva Sveučilišnog računskog centra (Srce) te pregled besplatnih stranih webinara u izboru CSSU-a.

Polaznici Centra različitih su razina formalnog obrazovanja. Riječ je o knjižničarima iz svih vrsta knjižnica, ali i polaznicima iz srodnih institucija, kao što su arhivi i muzeji, koji se u svom radu susreću s pitanjima prikupljanja, organiziranja, pretraživanja i upravljanja informacijama. Programe edukacije CSSU-a također pohađaju pomoćni knjižničari, stručni suradnici u školama (psiholozi, pedagozi...) te povremeno studenti informacijskih i komunikacijskih znanosti.

Budući da je program CSSU-a prema namjeni svojih tečajeva najviše usmjeren prema diplomiranim knjižničarima te njihovu daljnjem stručnom usavršavanju, pretpostavka je da će i njihov udio u ukupnom broju polaznika biti najveći. Cilj je rada stoga prikazati udio polaznika s visokom stručnom spremom, odnosno diplomiranih knjižničara u programima stručnog usavršavanja, godine staža u struci unutar te skupine, zastupljenost ponuđenih tematskih cjelina u izobrazbi, kao i razinu zadovoljstva ponuđenim sadržajima. Pri interpretaciji rezultata naznačeno je odstupanje raspoloživih podataka prikupljenih evaluacijskim upitnicima od ukupnog broja polaznika CSSU-a.

\section{Važnost trajne izobrazbe i usavršavanja u struci}

Za današnje generacije zaposlenika od velike je važnosti trajna izobrazba. Sam pojam upućuje na poseban oblik školovanja, usmjeren na uža, specifična znanja

5 Isto, str. 197. 
i vještine te se zbog toga odnosi na stručna i primjenjiva znanja u skladu s potrebama u struci. ${ }^{6}$

Iako su nova znanja i vještine ključan faktor opstanka i konkurentnosti na tržištu rada, treba naglasiti da je trajna izobrazba zaposlenika važna i za poslodavca.

Pritom treba uzeti u obzir da danas stručno usavršavanje ne podrazumijeva samo obuku, odnosno osposobljavanje za obavljanje određenih radnih zadataka, već cjelokupan proces razvoja zaposlenika, koji pridonosi razvoju same organizacije. ${ }^{7}$

Cilj stručnog usavršavanja jest osposobljavanje djelatnika za pružanje kvalitetnijih usluga, čime se u konačnici podiže i ugled same struke. ${ }^{8}$

Današnje generacije zaposlenika u kasnim 20-im, 30-im i ranim 40-im godinama, koje su naviknute na poslovnu neizvjesnost, svoju priliku vide u poznavanju novih tehnologija, izgradnji mreže stručnjaka te upravo u stalnom razvoju općih i stručnih kompetencija jer je na taj način moguće održati konkurentnost. ${ }^{9}$

Poželjni zaposlenici stoga moraju biti spremni na kontinuirano stručno usavršavanje.

Oblici stručnog usavršavanja vrlo su različiti. Osim samostalnog učenja i usavršavanja proučavanjem stručne literature ili sudjelovanjem na e-tečajevima, odnosno webinarima vezanim uz struku, zaposlenici mogu pohađati radionice, predavanja, stručne i znanstvene skupove i sl. Također, nove zaposlenike mogu obučavati, odnosno uvoditi u struku starije kolege, no oni također mogu ravnopravno sudjelovati u radnim zadacima ili projektima dijeleći na taj način znanja $\mathrm{i}$ iskustva (engl. peer mentoring).

Međutim proces usvajanja novih znanja i vještina ne ovisi samo o intrinzičnoj motivaciji zaposlenika nego i o radnim uvjetima te stimulativnosti u tom pogledu unutar same ustanove u kojoj rade u smislu mogućnosti napredovanja, ulaganja u izobrazbu i programe stručnog usavršavanja za zaposlenike i sl.

Tijekom projekta Cjeloživotno učenje knjižničara: ishodi učenja i fleksibilnost ${ }^{10}$ provedeno je istraživanje kojem je cilj bio „,definiranje stručnih i generičkih kompetencija u području knjižnično-informacijskih znanosti u Hrvatskoj iz per-

\footnotetext{
6 Izobrazba. // Hrvatska enciklopedija: mrežno izdanje. [citirano 2018-07-28]. Dostupno na: http://www.enciklopedija.hr/natuknica.aspx?id=28307.

7 Practical tips for developing your staff / Tracy Pratchett and Gil Young with Carol Brooks, Lisa Jeskins and Helen Monagle. London: Facet Publishing, 2016. Str. 27-28.

8 Horvat, A. Cjeloživotno učenje knjižničara u Hrvatskoj: stanje i mogućnosti. // Cjeloživotno učenje knjižničara: ishodi učenja i fleksibilnost / urednice Aleksandra Horvat i Dijana Machala. Zagreb: Nacionalna i sveučilišna knjižnica, 2009. Str. 26.

9 Practical tips. Nav. dj., str. 29.

10 Riječ je o jednogodišnjem projektu Nacionalne i sveučilišne knjižnice u Zagrebu, Odsjeka za informacijske znanosti Filozofskog fakulteta Sveučilišta u Zagrebu, Knjižnica grada Zagreba i Hrvatskog knjižničarskog društva. Projekt je odobren 2008. godine na natječaju „Reforma visokog školstva temeljem ishoda učenja“ Nacionalne zaklade za znanost, visoko školstvo i tehnologijski razvoj Republike Hrvatske. [citirano 2018-09-20]. Dostupno na: http://www.nsk.hr/cuk/index.htm.
} 
spektive poslodavaca i knjižničara te prikaz stanja i perspektive trajne izobrazbe knjižničara u kontekstu cjeloživotnoga učenja“. ${ }^{11}$

Prema rezultatima istraživanja, potrebu za trajnom izobrazbom knjižničara izražava 90 \% ravnatelja. Najčešći izvor programa trajne izobrazbe jesu seminari i konferencije u zemlji te edukacija u okviru CSSU-a. Razlozi su sudjelovanja u stručnom usavršavanju sljedeći: usavršavanje radnih sposobnosti, napredovanje, povećanje razine samopouzdanja, promjena radnog mjesta ili prelazak na nove poslovne zadaće. ${ }^{12}$

Zanimljivo je istaknuti da se mišljenja ravnatelja i knjižničara razlikuju vezano uz poželjne teme za usavršavanje u struci. Pritom ravnatelji ističu važnost komunikacijskih, socijalnih, i računalnih vještina, što upućuje na to da poslodavci, prije svega, traže od zaposlenika fleksibilnost i brzu prilagodbu na nove tehnologije i zahtjeve tržišta. Knjižničari s druge strane izražavaju potrebu za specifičnijim temama - vezanim uz organizaciju znanja, bibliografski nadzor, korisničke usluge, knjižnično poslovanje, upravljanje, marketing, financiranje i zagovaranje. Pritom treba naglasiti da su teme od interesa za stručno usavršavanje odraz postojećih potreba u smislu bolje radne učinkovitosti te ne podrazumijevaju podudaranje s kompetencijama i vještinama značajnim za struku. ${ }^{13}$

Kad je riječ o postojećem stanju trajne izobrazbe u knjižničarskoj struci, treba naglasiti da je uloga CSSU-a u povećanju stručnosti te usvajanju i razvoju novih kompetencija vrlo važna, s obzirom na to da kao nacionalni centar nudi različite oblike edukacije u vidu predavanja, radionica, e-tečajeva i webinara za knjižničare i stručnjake iz baštinskih ustanova na razini cijele Hrvatske.

\section{Cilj i metode istraživanja}

Pri istraživanju analizirani su evaluacijski upitnici koji su distribuirani polaznicima na području cijele Hrvatske od 2013. do 2017. godine. Evaluacijski upitnici sadrže pitanja o zadovoljstvu sadržajem tečaja, mogućnosti njegove primjene na trenutačno radno mjesto polaznika te zadovoljstvu predavačem. Usto, upitnici sadrže pitanja o stručnoj spremi polaznika, duljini radnoga staža u knjižnici te spremnosti polaznika da preporuči tečaj na kojem je sudjelovao kolegama.

Kako određeni broj upitnika polaznici nisu ispunili, naznačen je postotak, odnosno udio polaznika koji su popunili evaluacijske upitnike u ukupnom broju polaznika.

Budući da su programi stručnog usavršavanja i obrazovni sadržaji CSSU-a najviše usmjereni prema polaznicima nakon završenog visokoškolskog obrazova-

\footnotetext{
11 Machala, D. Knjižničarske kompetencije i trajna izobrazba knjižničara u Hrvatskoj: iz perspektive dionika na tržištu rada (poslodavaca i knjižničara). // Cjeloživotno učenje knjižničara: ishodi učenja i fleksibilnost / urednice Aleksandra Horvat i Dijana Machala. Zagreb: Nacionalna i sveučilišna knjižnica u Zagrebu, 2009. Str. 83

12 Isto, str. 119.

13 Isto, str. 121.
} 
nja, odnosno diplomiranim knjižničarima, pri analizi podataka krenulo se od pretpostavke da je udio polaznika s visokom stručnom spremom ${ }^{14} \mathrm{u}$ ukupnom broju polaznika najviši. Također je postojala pretpostavka kako je njihov broj tijekom godina konstantan s obzirom na objektivnu potrebu stalnog usavršavanja u struci te da će se kretati sukladno ukupnom broju polaznika u naznačenom razdoblju. Usto, očekivalo se da će polaznici s manje radnog iskustva biti spremniji na usavršavanje u struci te da će polaznici s duljim radnim stažem u knjižnici biti manje zastupljeni u programima izobrazbe.

Pri analizi podataka također su u obzir uzeti i arhivski podaci o pohađanju tečajeva u navedenom razdoblju, iz kojih je moguće iščitati interes polaznika za pojedine teme stručnog usavršavanja uz pregled najzastupljenijih tema.

$\mathrm{Na}$ temelju prikazanih podataka moguće je pratiti trendove kretanja te planirati daljnje korake u programima stručnog usavršavanja.

\subsection{Rezultati}

\subsubsection{Zastupljenost polaznika CSSU-a prema stručnoj spremi i trend kretanja}

Broj polaznika koji su ispunili evaluacijske upitnike, odnosno odgovorili na pitanje o stručnoj spremi u razdoblju od 2013. do 2017. iznosi 4438, što je 85,8 \% od ukupnog broja evidentiranih polaznika na tečajevima CSSU-a u tom razdoblju. Prema postojećim podacima, najveći broj polaznika CSSU-a ima visoku stručnu spremu (81 \%), slijede polaznici s magisterijem znanosti $(7 \%)$ i višom stručnom spremom $(6 \%)$, potom polaznici sa srednjom stručnom spremom (4\%) te na kraju polaznici s doktoratom znanosti (2\%), kako je prikazano na slici 1.

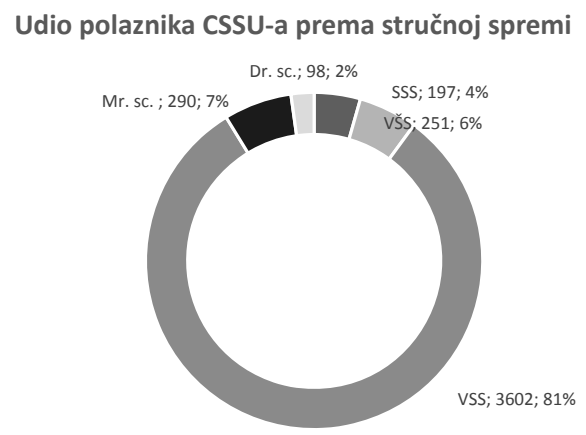

Slika 1. Udio polaznika CSSU-a prema stručnoj spremi od 2013. do 2017. godine

${ }_{14}$ Iako među polaznicima s visokom stručnom spremom ima primjerice stručnih suradnika $u$ školama, restauratora-konzervatora, djelatnika muzeja i arhiva, njihov je broj u ukupnom broju polaznika vrlo malen te u promatranom razdoblju iznosi u prosjeku oko $2 \%$ godišnje. 
Najveći udio polaznika programa Centra za stalno stručno usavršavanje knjižničara ima visoku stručnu spremu (VSS). Broj polaznika s VSS-om uglavnom je proporcionalan kretanju ukupnog broja polaznika te bilježi porast (slika 2).

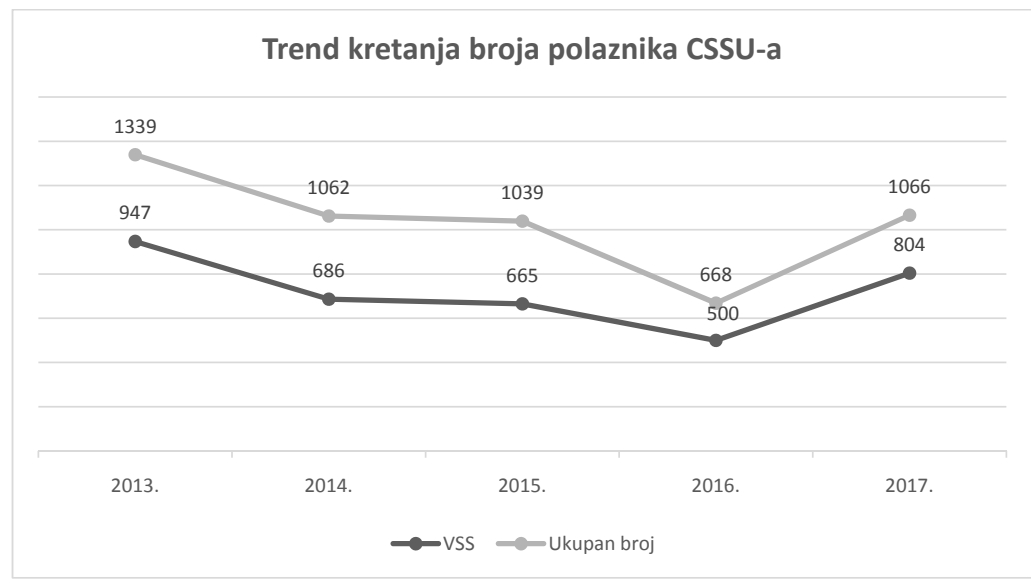

Slika 2. Kretanje ukupnog broja polaznika CSSU-a te polaznika s visokom stručnom spremom od 2013. do 2017. godine

\subsubsection{Staž polaznika s visokom stručnom spremom}

U obzir je uzet broj polaznika s visokom stručnom spremom - 3602 polaznika. Iz pojedinih napomena polaznika koji nisu odgovorili na ovo pitanje dalo se iščitati kako je jednim dijelom riječ o studentima, odnosno volonterima ili polaznicima druge struke (psiholozi, pedagozi, školski profesori...), koji su naznačili kako nemaju radnog iskustva u knjižnici.

Tablica 1. Broj polaznika s VSS-om prema radnom stažu u knjižnici od 2013. do 2017.

\begin{tabular}{|c|c|c|c|c|c|c|c|c|c|}
\hline & $\begin{array}{c}\mathbf{0 - 5} \\
\text { godina }\end{array}$ & $\begin{array}{c}\mathbf{6 - 1 0} \\
\text { godina }\end{array}$ & $\begin{array}{c}\mathbf{1 1 - 1 5} \\
\text { godina }\end{array}$ & $\begin{array}{c}\mathbf{1 6 - 2 0} \\
\text { godina }\end{array}$ & $\begin{array}{c}\mathbf{2 1 - 2 5} \\
\text { godina }\end{array}$ & $\begin{array}{c}\mathbf{2 6 - 3 0} \\
\text { godina }\end{array}$ & $\begin{array}{c}\text { Više od 30 } \\
\text { godina }\end{array}$ & $\begin{array}{c}\text { Bez } \\
\text { odgovora }\end{array}$ & Ukupno \\
\hline 2013. & 274 & 261 & 128 & 107 & 61 & 43 & 25 & 48 & 947 \\
\hline 2014. & 209 & 170 & 85 & 103 & 50 & 26 & 17 & 26 & 686 \\
\hline 2015. & 170 & 197 & 104 & 81 & 39 & 26 & 12 & 36 & 665 \\
\hline 2016. & 146 & 137 & 66 & 50 & 42 & 19 & 8 & 32 & 500 \\
\hline 2017. & 198 & 191 & 120 & 117 & 63 & 49 & 16 & 50 & 804 \\
\hline Ukupno & $\mathbf{9 9 7}$ & $\mathbf{9 5 6}$ & $\mathbf{5 0 3}$ & $\mathbf{4 5 8}$ & $\mathbf{2 5 5}$ & $\mathbf{1 6 3}$ & $\mathbf{7 8}$ & $\mathbf{1 9 2}$ & $\mathbf{3 6 0 2}$ \\
\hline
\end{tabular}


Iz dobivenih rezultata vidljivo je da broj polaznika obrazovnih programa CSSU-a opada s godinama staža. Pritom su najviše zastupljeni polaznici s visokom stručnom spremom koji imaju do 10 godina radnog staža, a najmanje polaznici koji imaju više od 30 godina radnog staža. Na ovo pitanje nisu odgovorila 192 polaznika, odnosno 5,37 \% ukupnog broja uzetog u razmatranje.

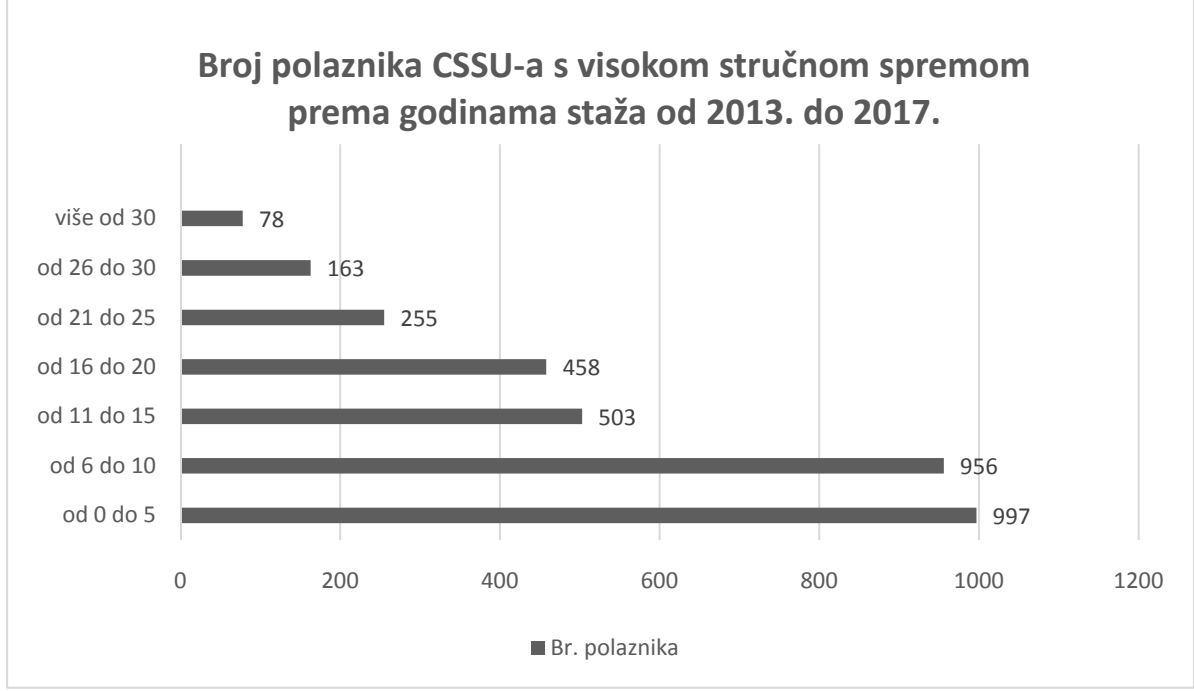

Slika 3. Broj polaznika CSSU-a s visokom stručnom spremom od 2013. do 2017. prema godinama radnog staža

3.1.3. Interes polaznika s visokom stručnom spremom za tematske cjeline (module) zastupljene u programu CSSU-a od 2013. do 2017.

Program je modularno strukturiran, prema tematskim cjelinama, odnosno potrebama polaznika iz različitih vrsta knjižnica. Pritom treba naglasiti da svi moduli ne sadrže jednak broj tečajeva. Njihov broj mijenja se iz godine u godinu dodavanjem ili isključivanjem pojedinih tečajeva iz programa. Najviše tečajeva tijekom promatranog razdoblja u prosjeku broje moduli II. Knjižnične službe i usluge te IV. Bibliografska kontrola.

Program sadrži sljedeće module, odnosno tematske cjeline (uz nazive modula dodan je prosječan broj tečajeva u razdoblju od 2013. do 2017. godine). 
Tablica 2. Tematske cjeline, odnosno moduli u programu CSSU-a od 2013. do 2017.

\begin{tabular}{|c|c|c|}
\hline $\begin{array}{c}\text { Broj } \\
\text { modula }\end{array}$ & Naziv modula & $\begin{array}{c}\text { Prosječan broj ponuđenih } \\
\text { tečajeva od 2013. do 2017. }\end{array}$ \\
\hline I. & $\begin{array}{c}\text { Intelektualna sloboda i pravna i etička } \\
\text { pitanja knjižničarske profesije }\end{array}$ & 5 \\
\hline II. & Knjižnične službe i usluge & 5 \\
\hline III. & Izgradnja zbirki & 14 \\
\hline IV. & Bibliografska kontrola & 10 \\
\hline V. & $\begin{array}{c}\text { Vrednovanje, istraživanje i projektno } \\
\text { upravljanje }\end{array}$ & 12 \\
\hline VI. & $\begin{array}{c}\text { Elektronički informacijski izvori i službe } \\
\text { (od 2014. Elektronički informacijski } \\
\text { izvori i sistemsko knjižničarstvo) }\end{array}$ & 3 \\
\hline VII. & Nakladništvo & 2 \\
\hline VIII. & Digitalizacija građe & 2 \\
\hline IX. & E-učenje (do 2015.) & 2 \\
\hline X. & Trening trenera15 & 2 \\
\hline
\end{tabular}

Izbor tečajeva iz programa koji će biti održani tijekom određene godine ovisi o suradnji sa županijskim matičnim knjižnicama, sveučilišnim knjižnicama i knjižničarskim društvima te je u skladu s potrebama stručne zajednice za programima trajne izobrazbe. Osim toga, izbor ovisi i o dogovoru s partnerskim institucijama te iskazanim potrebama za određenim temama. Također se vodi računa o tome da se u Nacionalnoj i sveučilišnoj knjižnici svake godine predstave aktualni tečajevi uvršteni u program CSSU-a. Edukacija se planira i u skladu s upitima i interesom polaznika za pojedine teme. U prikazu rezultata u obzir su uzeta i gostovanja stranih predavača za koja su postojali relevantni podaci o polaznicima.

15 Riječ je o izobrazbi predavača CSSU-a, kojima je ponuđeno sudjelovanje na tečajevima vezanim uz prezentacijske i komunikacijske vještine. 


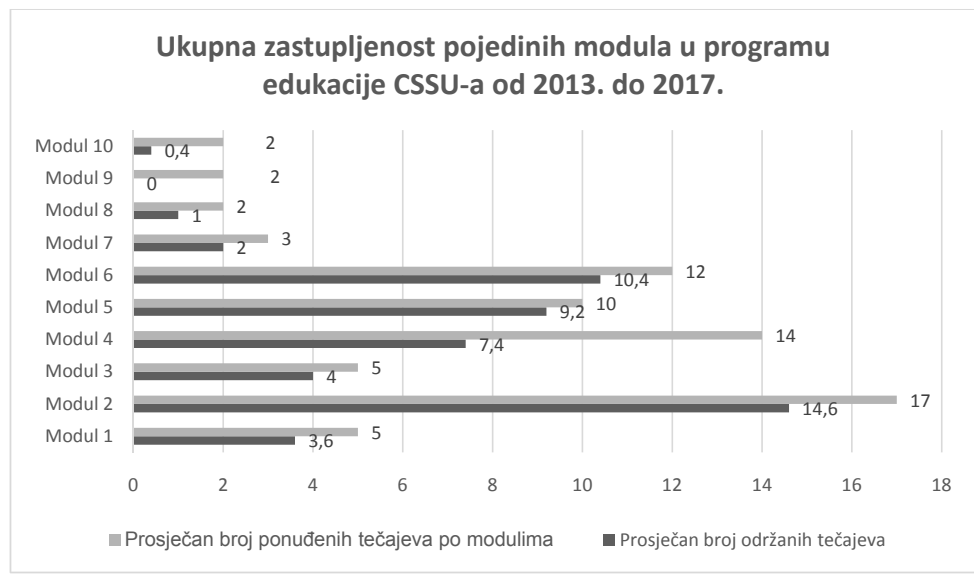

Slika 4. Prosječan broj ponuđenih i prosječan broj održanih tečajeva unutar pojedinih modula u programu CSSU-a od 2013. do 2017. godine

$\mathrm{Na}$ prikazanom grafikonu vidljivo je da je najviše održanih tečajeva iz najbrojnije skupine, odnosno modula II. Knjižnične službe i usluge. Međutim iako je drugi po redu po broju ponuđenih tečajeva modul IV. Bibliografska kontrola, u razdoblju od 2013. do 2017. češće su se održavali tečajevi iz modula VI. Elektronički informacijski izvori i sistemsko knjižničarstvo te iz modula V. Vrednovanje, istraživanje i projektno upravljanje. Treba napomenuti da se interes za pojedine module ponešto razlikuje ovisno o stručnoj spremi polaznika. Interes polaznika s visokom stručnom spremom za tečajeve CSSU-a iskazan je na slici 5.

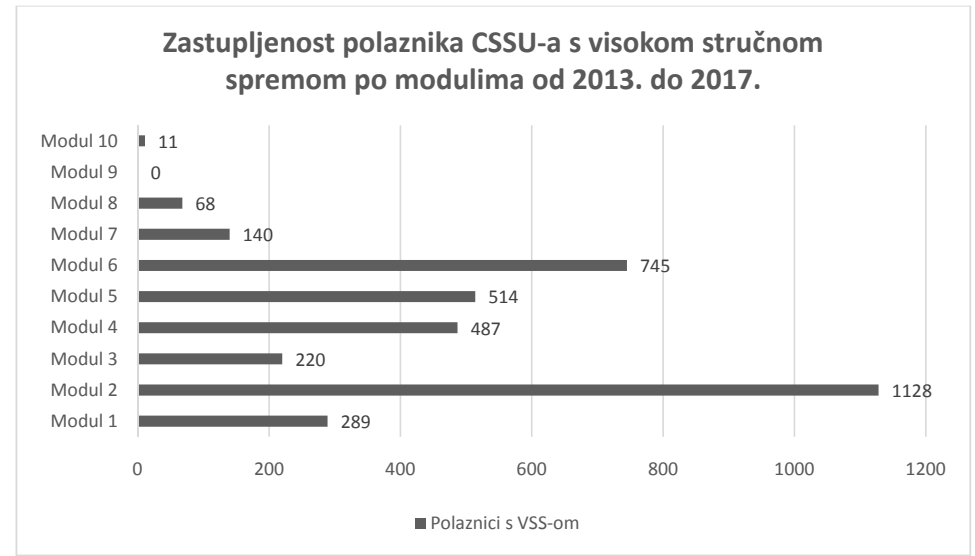

Slika 5. Zastupljenost polaznika CSSU-a s visokom stručnom spremom po modulima koje su pohađali od 2013. do 2017. godine 
3.1.4. Zadovoljstvo polaznika s visokom stručnom spremom sadržajem i predavačima na tečajevima CSSU-a te primjenjivost sadržaja tečajeva na radna mjesta polaznika

Analizom evaluacijskih listića u razdoblju od 2013. do 2017. dobiveni su sljedeći rezultati:

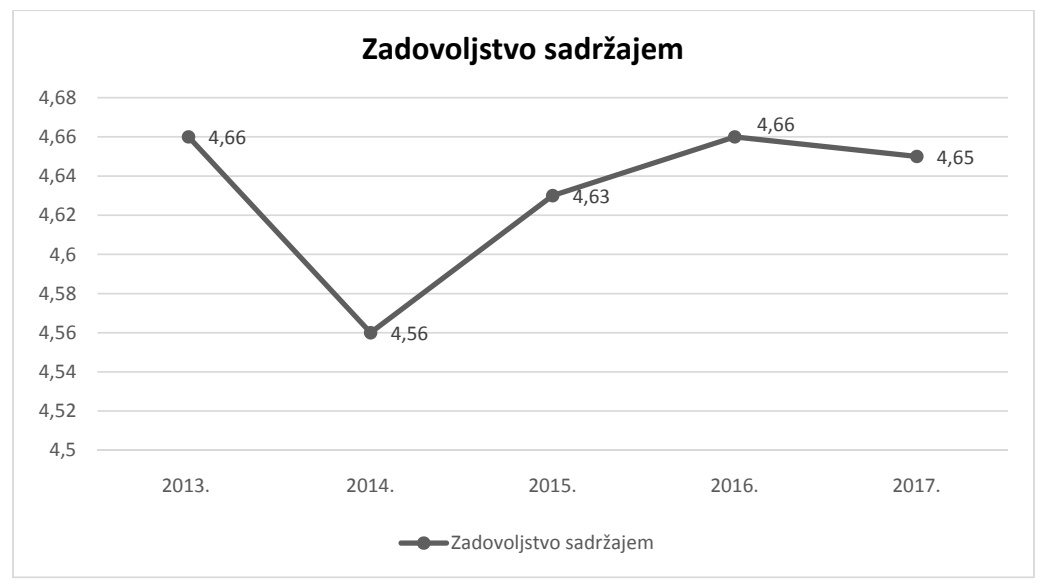

Slika 6. Zadovoljstvo polaznika CSSU-a s visokom stručnom spremom sadržajem tečajeva koje su pohađali od 2013. do 2017. godine

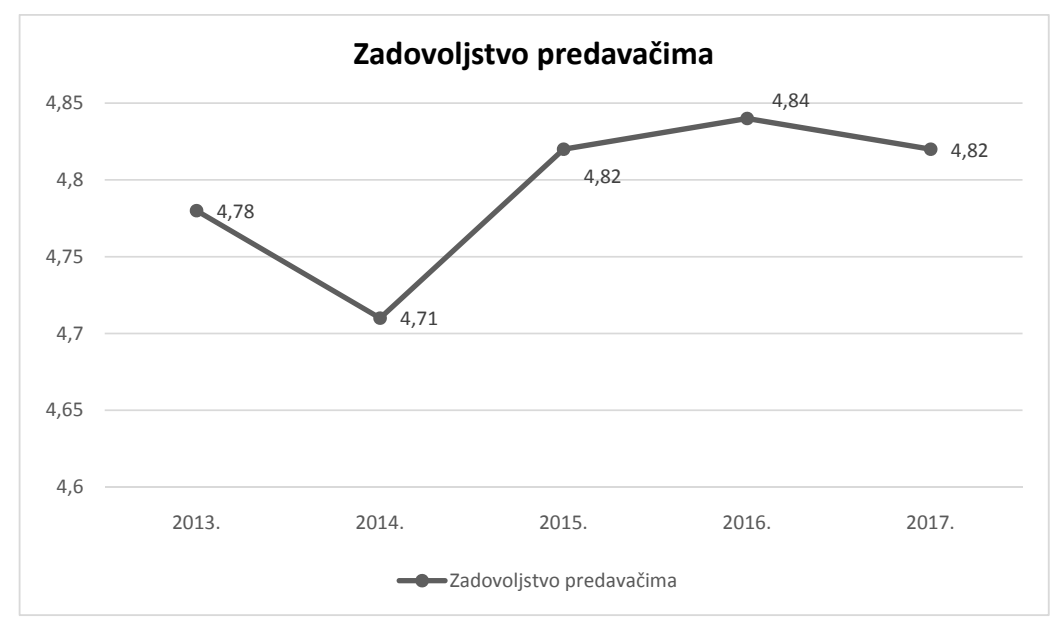

Slika 7. Zadovoljstvo polaznika CSSU-a s visokom stručnom spremom predavačima na tečajevima koje su pohađali od 2013. do 2017. godine 
$\mathrm{Na}$ temelju prikazanih rezultata vidljivo je kako su polaznici pokazali visoku razinu zadovoljstva sadržajem tečajeva te predavačima. Treba napomenuti da se programi izobrazbe svake godine ažuriraju te nadopunjuju novim sadržajima kako bi adekvatno odgovorili na aktualna pitanja vezana uz struku, ali i na potrebe polaznika iz različitih vrsta knjižnica.

Od 2013. do 2016. godine putem evaluacijskih listića na pitanje mogu li sadržaj tečaja primijeniti na radnom mjestu $67(2,4 \%)$ polaznika odgovorilo je da ne može, 1118 (40 \%) odgovorilo je da može djelomično, a 1613 (57, 6\% ) da može u velikoj mjeri.

Godine 2017. u evaluacijskom upitniku na pitanje o primjenjivosti sadržaja na radno mjesto polaznika ponuđeni su odgovori od 1 do 5 te je njihov prosjek iznosio 4,23 .

\subsubsection{Spremnost polaznika s visokom stručnom spremom da preporuče tečajeve CSSU-a kolegama}

Od ukupno 3602 ispitanika, na upit bi li preporučili tečaj CSSU-a na kojem su bili svojim kolegama pozitivno je odgovorilo 3451 ispitanika, odnosno 95,8 $\%$, negativno je odgovorilo 122 ispitanika, tj. 3,4\%, a 29 ispitanika ili 0,8\% nije odgovorilo na to pitanje.

\section{Spremnost polaznika CSSU-a da preporuče tečajeve kolegama u razdoblju od 2013. do 2017.}

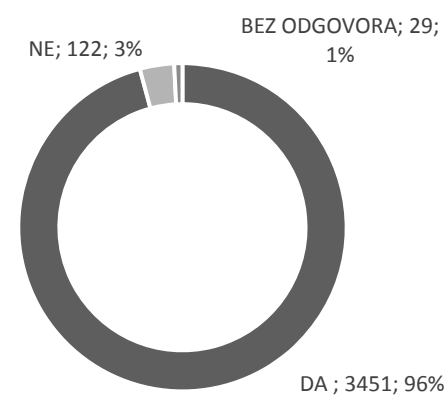

Slika 8. Spremnost polaznika CSSU-a s visokom stručnom spremom da preporuče tečajeve koje su pohađali kolegama u razdoblju od 2013. do 2017. godine 


\section{Interpretacija rezultata}

Svi rezultati promatrani su u razdoblju od 2013. do kraja 2017. godine.

Prema iznesenim podacima, najviše je polaznika CSSU-a s visokom stručnom spremom - 3602 polaznika, odnosno $81 \%$, slijedi 290 polaznika (7 \%) s magisterijem znanosti i 251 polaznik (6 \%) s višom stručnom spremom, 197 (4 \%) polaznika sa srednjom stručnom spremom te 98 polaznika $(2 \%)$ s doktoratom znanosti (slika 1).

Potvrđena je pretpostavka vezana uz udio visokoobrazovanih polaznika, koji se očekivano pokazao najvećim, s obzirom na namjenu samih tečajeva te programa izobrazbe CSSU-a u cjelini.

Broj polaznika s visokom stručnom spremom bio je u padu između 2013. i 2016. godine (slika 2), što se može pripisati i generalno smanjenom broju polaznika u tom razdoblju. Međutim već 2017. godine broj polaznika s visokom stručnom spremom bilježi trend rasta.

Treba naglasiti da sve kategorije polaznika po stručnoj spremi bilježe blagi rast tijekom 2017. godine u odnosu na prethodnu, 2016. godinu, s obzirom na općenito povećanje broja tečajeva, sati edukacije te polaznika. ${ }^{16}$

Pretpostavka vezana uz radni staž polaznika također je potvrđena. Iz rezultata analize vidljivo je kako najveći broj polaznika programa CSSU-a s visokom stručnom spremom ima do 10 godina radnog staža te da broj polaznika s godinama radnog staža opada (tablica 1 ; slika 3 ).

Mlađi zaposlenici nemaju radnog iskustva, ali u se tom pogledu može pretpostaviti i kako dio mlađih zaposlenika nema trajno zaposlenje te se nastoji educirati u različitim područjima i pratiti novitete u struci zbog konkurentnosti u pronalaženju posla. Također je važno istaknuti da su današnje generacije koje ulaze na tržište rada spremnije i pripremljenije za trajnu izobrazbu zbog poslovne nesigurnosti, ali i zbog želje za dinamikom, promjenom radnog mjesta i učenjem. Usto se može pretpostaviti kako zaposlenici s više radnog staža imaju i više radnog iskustva te da u određenim segmentima mogu preuzeti ulogu mentora za nove zaposlenike.

Kad je riječ o tematskim cjelinama, najzastupljenija cjelina, odnosno modul unutar programa CSSU-a s najviše ponuđenih tečajeva jest II. Knjižnične službe $i$ usluge (tablica 2). Modul obuhvaća tečajeve vezane uz rad s različitim skupinama korisnika, usluge za osjetljivije skupine korisnika, poticanje čitanja, zaštitu knjižnične građe, pokretne knjižnice, međuknjižničnu posudbu i sl. Unutar spomenutog modula realiziralo se i najviše tečajeva od 2013. do 2017. godine (slika 4). Iako po broju ponuđenih tečajeva slijedi modul IV. Bibliografska kontrola, veći broj održanih tečajeva u promatranom razdoblju bilježi se unutar modula VI. Elektronički

16 Budući da 2016. godine CSSU nije dobio financijsku potporu Ministarstva kulture, ukupan broj održanih tečajeva i sati edukacije, kao i broj polaznika, zabilježili su osjetan pad. 
informacijski izvori i sistemsko knjižničarstvo ${ }^{17}$, koji obuhvaća tečajeve vezane uz izradu mrežnih stranica, upravljanje informacijama na internetu, društvene medije, otvoren pristup informacijama, digitalne repozitorije, semantički web i sl. Treće mjesto po broju održanih tečajeva zauzima modul $V$. Vrednovanje, istraživanje $i$ projektno upravljanje, koji obuhvaća teme vezane uz metodologiju anketnih istraživanja, vrednovanje znanstvene produktivnosti, bibliometrijske usluge knjižnica, norme vezane uz knjižničarstvo i sl. Polaznici koji imaju visoku stručnu spremu pokazali su također najveći interes za navedene tematske cjeline, odnosno module u okviru programa (slika 5).

$\mathrm{Na}$ odaziv zainteresiranih polaznika zasigurno utječu promjene i noviteti u struci, a ponekad primjerice postoji mogućnost da se isti tečaj održi više puta po cijeloj Hrvatskoj u istoj godini jer je tematika kojom se bavi u tom trenutku aktualna, pa je prikazani broj polaznika tog modula veći.

Treba naglasiti da je na mrežnim stranicama CSSU-a dostupna anketa o najvažnijim temama stručnog usavršavanja, koju polaznici mogu popuniti te čiji se rezultati uzimaju u obzir pri planiranju edukacijskih programa. Trenutačno je najveći broj posjetitelja zainteresiran za područje Upravljanje i razvoj korisničkih službi i usluga $^{18}$, što je u skladu s najzastupljenijim temama ponuđenim u okviru programa CSSU-a i velikim brojem polaznika koji su pohađali tečajeve vezane uz to područje.

Također treba dodati da je poziv na predlaganje tečajeva stalno otvoren te dostupan na mrežnim stranicama CSSU-a. Prijedlozi koji pristižu najčešće su također vezani uz aktualnu tematiku, izazove i rješenja s kojima se zaposlenici susreću na radnim mjestima, s obzirom na to da je jedan od ciljeva tečajeva i radionica CSSU-a svakako i razmjena iskustava te upoznavanje polaznika s dobrim primjerima iz prakse.

U skladu s tim, treba istaknuti i dobivene rezultate vezane uz zadovoljstvo polaznika odslušanim sadržajima, odnosno tečajevima na kojima su sudjelovali. Zadovoljstvo sadržajem tečajeva, kao i predavačima, vrlo je visoko. Iako je 2014. godine uočljiv blagi pad, naznačene vrijednosti idućih su godina u porastu te iskazuju kontinuirano visoku razinu (slike 6 i 7).

Rezultati vezani uz primjenjivost sadržaja izobrazbe na radno mjesto polaznika upućuju na to da najveći dio polaznika dolazi na tečajeve u svrhu stručnog usavršavanja u području kojim se trenutačno bavi. Međutim velik broj polaznika obrazovni sadržaj može tek djelomično primijeniti, što upućuje na to da se dio polaznika želi usavršavati i u područjima koja nisu usko vezana uz postojeće radno mjesto, što može biti odraz nesigurnosti na tržištu rada, ali i tendencije mlađih zaposlenika za širom izobrazbom unutar struke.

17 Do 2014. nosi naziv Elektronički informacijski izvori i službe.

18 Anketa Centra za stalno stručno usavršavanje knjižničara o najvažnijim temama stručnog usavršavanja. [citirano 2018-08-01]. Dostupno na: http://cssu.nsk.hr/. 
Najviše polaznika, njih 3451 (95,8 \%), preporučilo bi tečaj CSSU-a na kojem su sudjelovali svojim kolegama. Njih $122(3,4 \%)$ ne bi preporučilo tečaj, dok je 29 polaznika $(0,8 \%)$ bez odgovora (slika 8$)$. Visoki rezultati vezani uz preporuku kolegama govore u prilog tomu da tečajevi odgovaraju svojoj namjeni i svrsi.

\section{Zaključak}

Budući da današnje prilike na tržištu rada zahtijevaju stalnu prilagodbu i razvoj znanja, vještina i kompetencija od zaposlenika, formalno obrazovanje može se smatrati samo prvom stepenicom u procesu profesionalnog razvoja. U svrhu napredovanja, kvalitetnijeg obavljanja poslovnih zadataka, ali i osobnog razvoja, zaposlenici poduzimaju različite aktivnosti neformalnog i informalnog učenja kao što su prisustvovanje tečajevima, radionicama, webinarima, sudjelovanje i izlaganja na stručnim i znanstvenim skupovima, praćenje stručne literature i sl.

CSSU provodi program cjeloživotnog učenja i stalnog stručnog usavršavanja za širu AKM-zajednicu te nudi tečajeve, predavanja i radionice svojim polaznicima. Tečajevi su modularno, odnosno tematski strukturirani kako bi se obuhvatila područja za polaznike iz različitih vrsta knjižnica, odnosno ustanova. Tečajevi su kreirani prema namjeni, a najviše su zastupljeni tečajevi usmjereni prema polaznicima nakon visokoškolskog obrazovanja.

Na temelju dobivenih rezultata može se zaključiti kako je trajna izobrazba važna i aktualna, a usavršavanje u struci u svrhu učinkovitijeg obavljanja radnih zadataka i konkurentnosti na tržištu rada očekivan korak nakon formalnog obrazovanja. Naime u programu CSSU-a u prikazanom razdoblju sudjelovali su polaznici različitih razina formalnog obrazovanja - od srednje stručne spreme do doktorata znanosti, što govori u prilog važnosti cjeloživotnog učenja i profesionalnog razvoja.

Najviše je polaznika s visokom stručnom spremom (81 \%), a najmanje polaznika s doktoratom znanosti (98 polaznika, odnosno $2 \%$ od 2013. do 2017.), no važno je na temelju tog podatka naglasiti da su se i polaznici s magisterijem, odnosno doktoratom znanosti i dalje spremni profesionalno razvijati te usvajati nova znanja i vještine. Njihov je udio malen, no treba napomenuti da je njihov broj i općenito malen u knjižničarskoj zajednici.

Zaposlenici s manje radnog iskustva spremniji su na učenje i usavršavanje u struci. Zbog promjena i nestabilnosti na tržištu rada mlađe generacije otvorenije su različitim sadržajima unutar profesije te mogućnosti promjene posla. Tomu u prilog govore i rezultati vezani uz primjenjivost sadržaja izobrazbe na radno mjesto polaznika.

Trendovi kretanja općenito se mogu promatrati kao putokaz u planiranju daljnje izobrazbe. U tom kontekstu važno je identificirati teme od interesa za pojedine skupine polaznika te trajno pratiti trendove kretanja. Jedan od pokazatelja jest $i$ anketa 
o najvažnijim temama stručnog usavršavanja, dostupna na mrežnim stranicama CSSU-a, kao i suradnja s matičnim knjižnicama, sveučilišnim knjižnicama te regionalnim knjižničarskim društvima, koji prepoznaju potrebe na terenu te u tom smislu mogu izraziti svoje sugestije te ukazati na trenutačne potrebe za edukacijom.

Visoka razina zadovoljstva polaznika s visokom stručnom spremom sadržajem tečajeva te predavačima CSSU-a, kao i spremnost da preporuče tečajeve na kojima su sudjelovali kolegama, svakako je poticaj za daljnje unapređivanje programa trajne izobrazbe i obogaćivanje novim oblicima učenja i poučavanja te povećanja dostupnosti. Pritom je naglasak stavljen na e-učenje, odnosno edukaciju putem webinara.

\section{LITERATURA}

Anketa Centra za stalno stručno usavršavanje knjižničara o najvažnijim temama stručnog usavršavanja. [citirano 2018-08-01]. Dostupno na: http://cssu.nsk.hr/.

Cjeloživotno učenje knjižničara (CUK): ishodi učenja i fleksibilnost. [citirano 2018-0920]. Dostupno na: http://www.nsk.hr/cuk/index.htm.

Horvat, A. Cjeloživotno učenje knjižničara u Hrvatskoj: stanje i mogućnosti. // Cjeloživotno učenje knjižničara: ishodi učenja i fleksibilnost / urednice Aleksandra Horvat i Dijana Machala. Zagreb: Nacionalna i sveučilišna knjižnica, 2009. Str. 21-36.

Izobrazba. // Hrvatska enciklopedija: mrežno izdanje. [citirano 2018-07-28].

Dostupno na: http://www.enciklopedija.hr/natuknica.aspx?id=28307.

Machala, D. Knjižničarske kompetencije i trajna izobrazba knjižničara u Hrvatskoj: iz perspektive dionika na tržištu rada (poslodavaca i knjižničara). // Cjeloživotno učenje knjižničara: ishodi učenja i fleksibilnost / urednice Aleksandra Horvat i Dijana Machala. Zagreb: Nacionalna i sveučilišna knjižnica, 2009. Str. 83-124.

Machala, D. Knjižničarske kompetencije: pogled na razvoj profesije. Zagreb: Hrvatska sveučilišna naklada: Nacionalna i sveučilišna knjižnica, 2015.

Machala, D. Uklopljeno knjižničarstvo : model knjižničarske djelatnosti novog vremena. // Revija Knjižnica 60, 1(2016), str. 113-133. [citirano: 2018-09-20]. Dostupno na: https://knjiznica.zbds-zveza.si/knjiznica/issue/view/575.

Pastuović. N. Cjeloživotno učenje i promjene u školovanju. // Odgojne znanosti 10, 2(2008), str. 253-267. [citirano: 2018-07-20]. Dostupno na: https://hrcak.srce.hr/index.php?show=clanak\&id_clanak_jezik=46484.

Practical tips for developing your staff / Tracy Pratchett and Gil Young with Carol Brooks, Lisa Jeskins and Helen Monagle. London: Facet Publishing, 2016.

Shumaker, D. Embedded librarian: innovative strategies for taking knowledge where it's needed. Medford, New Jersey: Information today, 2012. 